\title{
25. EARLY CRETACEOUS FORAMINIFERA FROM THE NORTHWESTERN PACIFIC: LEG 32 OF THE DEEP SEA DRILLING PROJECT
}

\author{
Hanspeter Luterbacher, Esso Production Research-European, 33321 Bègles (France)

\section{INTRODUCTION}

\section{SUBDIVISION AND AGE SIGNIFICANCE OF FORAMINIFERAL ASSEMBLAGES}

During Leg 32 (Hakodate, Japan, to Honolulu, Hawaii), Early Cretaceous deposits were penetrated at five sites. Two sites are located on the Japanese magnetic lineations (Sites 303 and 304), two on Shatsky Rise (Sites 305 and 306), and one on the Hawaiian magnetic lineations (Site 307) (see Figure 1). Details of location, coring, and lithology at these sites can be found in the corresponding site report chapters in this volume.

At all sites, recovery of Early Cretaceous sediments was poor to very poor. From many cored intervals, recovery consists only of chert chips or cuttings of doubtful origin. Therefore, a large number of cores yielded no sediments which could be washed for microfossils, and in many others, only traces of sediment in insufficient quantities for washing were obtained.

As a rule, foraminiferal faunas are few and poorly preserved. Large portions of the sections are devoid of foraminifera. In Figure 1, the intervals with characteristic foraminiferal faunas and those with only poor and uncharacteristic faunules are indicated. At Sites 303 and 304 , foraminifera occur only in the two sediment cores immediately above the basalt. At Site 307, the entire interval dated as Cretaceous, based on other groups of microfossils, contains only a single specimen of Glomospira (Core 2) and two specimens of Haplophragmoides (Core 5).

Only Sites 305 and 306 on Shatsky Rise furnished a sequence of Early Cretaceous foraminiferal faunas which allows the dating of some intervals. However, even at these sites the distribution of foraminiferal faunas is too patchy and their preservation and composition is too poor to allow a satisfactory subdivision comparable to those established in well-known sections of corresponding age.

The subdivision based on foraminifera of the Early Cretaceous deposits cored during Leg 32, discussed below, is very tentative. It will have to be followed and modified in the future by taxonomic discussions and illustrations of the foraminiferal species used in it. The lagenids, which commonly dominate the washed residues, need a more detailed treatment. The determinations of lagenids given in this chapter are merely intended to indicate the form groups represented without taking into account their range of variability which often transgresses the limits between too rigidly defined genera. For the same reason, only well-documented species names are used.

Early Cretaceous foraminifera from Sites 303 and 304 are listed in Appendix A. Ostracodes from Sites 305 and 306 were examined by H.J. Oertli, and his determinations are listed in Appendix B.
Interval with Rotalipora brotzeni (Sigal), $R$. greenhornensis (Morrow), and $R$. gandolfii Luterbacher and Premoli Silva; Early Cenomanian (Site 305, Cores 37 to 41)

The distribution of microfaunas within this interval is very irregular. The preservation of the planktonic foraminifera varies from good to poor and their occurrences are rather spotty (for details, see distribution chart, Figure 2). The pieces of green-gray laminated siliceous chalk in the core catcher of Core 40 contain almost no planktonic foraminifera, yet they are very abundant and well preserved in the cuttings of the more calcareous chalk found in the same core catcher.

The coexistence of Rotalipora brotzeni (Sigal) (Cores 37 to 40), $R$. greenhornensis (Morrow) (Core 39), and $R$. gandolfii Luterbacher and Premoli Silva (Cores 39 to 41) indicates an early Cenomanian age. These Rotalipora are associated with other planktonic species characteristic for late Albian and early Cenomanian assemblages, e.g., Rotalipora evoluta Sigal, Hedbergella amabilis Loeblich and Tappan, H. brittonensis Loeblich and Tappan, Globigerinelloides eaglefordensis (Moreman). Typical Rotalipora apenninica (Renz) occur highest in the cuttings from the core catcher of Core 41 .

The composition of the benthonic foraminiferal assemblages is rather variable (Figure 2). Noteworthy is the presence of Conorotalites sp. aff. C. aptiensis (Bartenstein) in Core 40. A similar form has been described by Moullade (1966) from the late Albian (to Cenomanian?) of southeastern France. In northwestern Europe, Conorotalites aptiensis has a range from late Barremian to middle Albian, but is mainly found in the Aptian (Bartenstein et al., 1962). Occurrences of this form in the late Albian, however, are reported elsewhere (e.g., Risch, 1969). Gubkinella? graysonensis (Tappan) is common in several samples. This species is reported from the Aptian (or even late Barremian) to the Cenomanian (Michael, 1972; Longoria, 1972; Bolli, 1959). Osangularia californica Dailey (probably a junior synonym of Osangularia utaturensis [Sastry and Sastri] according to Scheibner, 1974) has its highest occurrence in Core 41. O. californica Dailey was first described from the Lower Cretaceous (Aptian to Albian?) of northern California.

Interval with Rotalipora apenninica (Renz); Late Albian (to basal Cenomanian) (Site 305, Cores 42 to 46; Site 306, Cores 2[?] and 3)

The distribution and preservation of the planktonic foraminifera is also very patchy (Figure 3 ). 


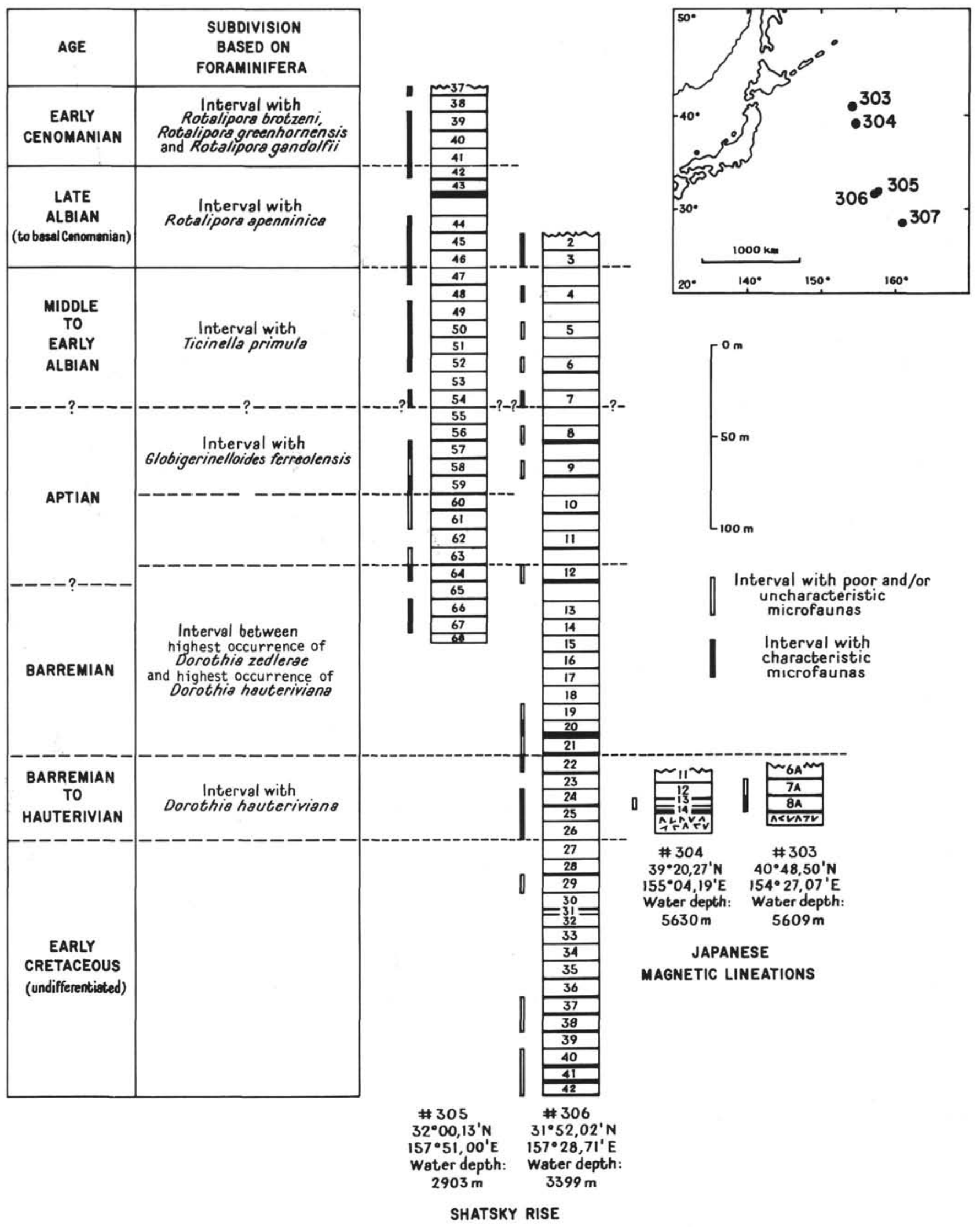

Figure 1. Subdivision and correlation based on foraminifera of the Lower Cretaceous in Sites 303, 304, 305, and 306. 


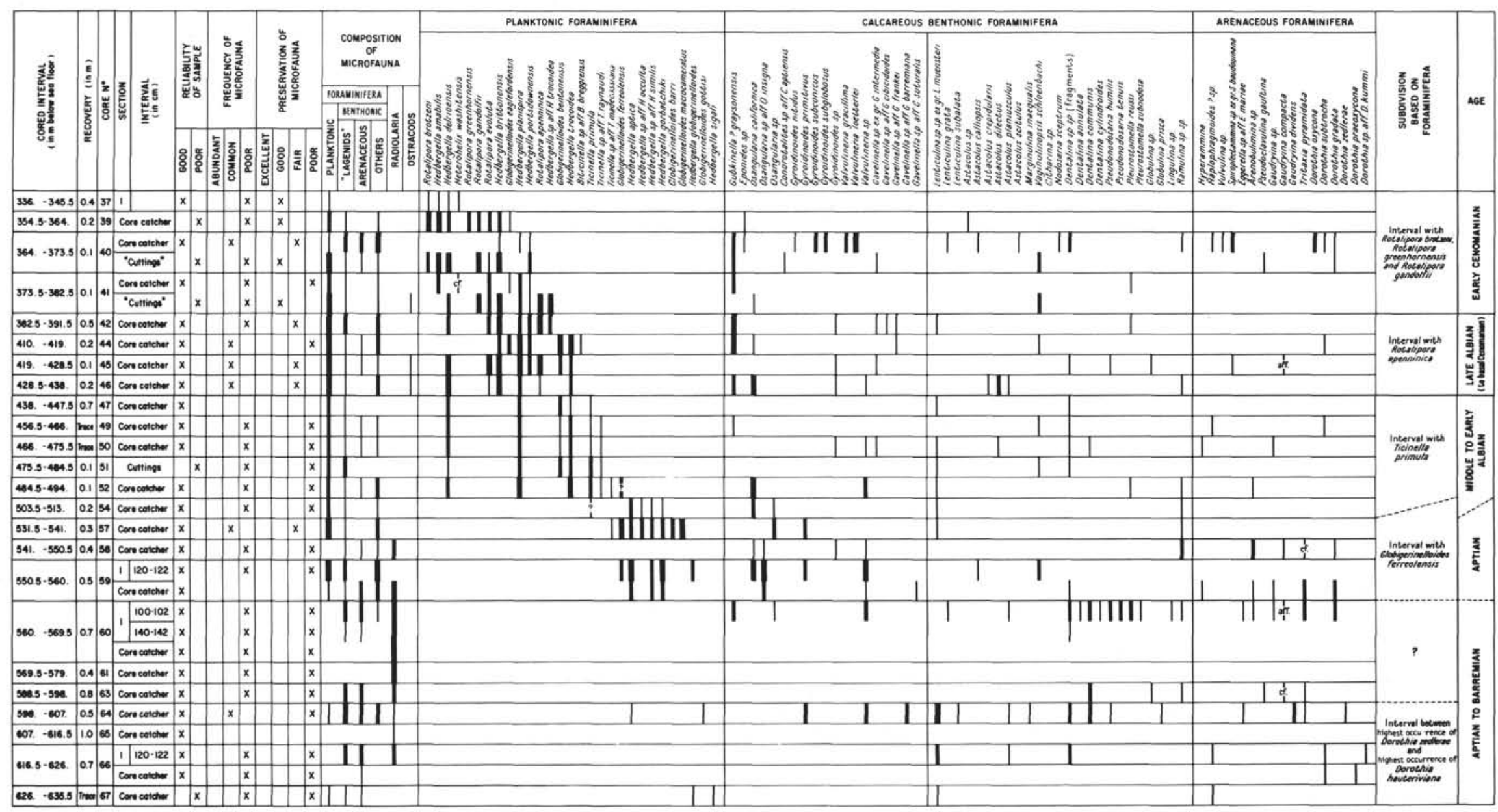

Figure 2. Distribution of foraminifera of the Lower Cretaceous of Site 305. 


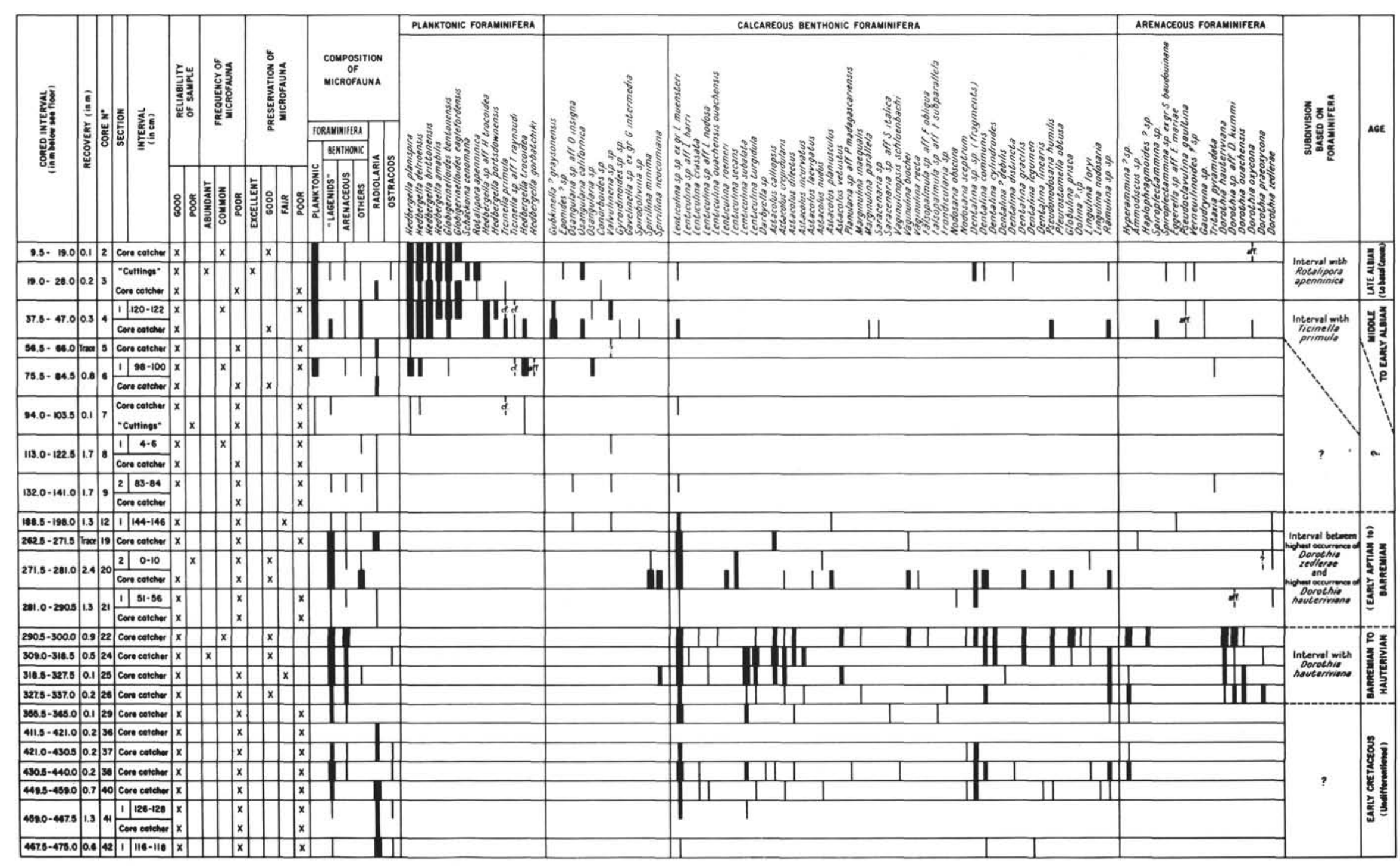

Figure 3. Distribution of foraminifera of the Lower Cretaceous of Site 306. 
The presence of Rotalipora apenninica (Renz) (sensu Luterbacher and Premoli Silva, 1962, =Rotalipora balernaensis Gandolfi sensu Sigal, 1969) and $R$. evoluta Sigal indicates a late Albian (to basal Cenomanian) age.

At Site 306, representatives of the genus Rotalipora are only found in Core 3, but Core 2 contains the same Hedbergella species as found in Core 3 and therefore is placed into the same interval. The cuttings from Core 3 are relatively rich in well-preserved specimens of Schackoina cenomana (Schacko).

The distribution of the benthonic foraminifera in this interval is shown in Figures 2 and 3.

Interval with Ticinella primula Luterbacher; Early to Middle Albian (Site 305, Cores 47 to 52 [or 54?]; Site 306, Core 4 [to 7?])

Because of the generally poor preservation of the microfaunas, the accessory apertures typical for the genus Ticinella cannot always be seen clearly. The presence of Ticinella primula in Core 54 of Site 305 and in Core 7 of Site 306 is therefore uncertain.

The earliest occurrence of representatives of the genus Ticinella is within the youngest part of the Aptian (Sigal, 1966; Longoria, 1972) or at the base of the Albian (Gorbatchik and Kretschmar, 1969). Older occurrences cited in the literature are very doubtful (e.g., middle Barremian in Fuchs, 1972). Ticinella primula ranges throughout the Albian (Sigal, 1966), although it may have its first occurrence in the uppermost Aptian (Longoria, 1972). The limit between the Aptian and Albian is here drawn in coincidence with the lowermost occurrence of representatives of the genus Ticinella.

Interval with Globigerinelloides ferreolensis (Moullade); Aptian (Site 305, Cores 57 [or 54?] to 59)

At Site 306, this interval could not be recognized. Samples from the cores between the lowermost occurrence of planktonic foraminifera and the highest occurrence of Dorothia zedlerae (Moullade) (Cores 8 to 11) are either barren or contain only very poor and uncharacteristic faunules.

The most representative microfauna of this interval is found in the core-catcher sample of Core 57 (Site 305). Globigerinelloides ferreolensis (Moullade) is here accompanied by G. barri (Bolli, Loeblich, and Tappan), G. macrostomata Longoria, Hedbergella aptica (Agalarova), $H$. gorbatchiki Longoria, and $H$. globigerinelloides (Subbotina). A few specimens of Globigerinelloides ferreolensis display a strong tendency to uncoil and in this respect resemble $G$. algerianus Cushman and Ten Dam, but they always have fewer chambers and lack the flattened profile typical for the latter species.

According to most authors, Globigerinelloides ferreolensis is restricted to the late Aptian (mainly "Gargasian") (e.g., Moullade, 1966; Gorbatchik and Kretschmar, 1969; Longoria, 1972). According to Sigal (1966), the species ranges from within the upper part of the early Aptian ("Bedoulian") into the upper part of the late Aptian ("Clansayesian"). G. barri (Bolli, Loeblich, and Tappan) and G. macrostomata Longoria are restricted to the late Aptian (Longoria, 1972).
The composition of the microfaunas from this interval strongly resembles those from the "zone à Globigerinelloides" of French authors (e.g., Sigal, 1966) ("Gargasian"), although Globigerinelloides algerianus, the most prominent marker of this zone, has not been found.

Interval Between Highest Occurrence of Dorothia zedlerae (Moullade) and Highest Occurrence of Dorothia hauteriviana (Moullade); Early Aptian? to Barremain (Site 305, Cores 64 to 67; Site 306, Cores 12 to 21)

At Site 305, samples from Cores 60 to 63 are dominated by Radiolaria. Only samples from Section 1 of Core 60 and the core catcher of Core 63 contain a few benthonic foraminifera. Gubkinella? graysonensis (Tappan) and Osangularia sp. aff. $O$. insigna Dailey have their lowermost occurrences in Core 60.

Dorothia zedlerae (Moullade) appears in Core 64 of Site 305 and in Core 12 of Site 306. A comparison of the two sections, with the lowermost occurrence of Rotalipora apenninica as a datum, indicates that the first occurrence takes place at the same subsea depth. At both sites, Dorothia praeoxycona Moullade and Dorothia sp. aff. D. kummi (Zedler) appear below the first occurrence of $D$. zedlerae.

Dorothia zedlerae is known from the late Valanginian to the early Barremian, $D$. praeoxycona from the Barremian to the basal Albian and D. kummi from the late Valanginian to the Aptian (Moullade, 1966; Douglas and Moullade, 1972). However, the stratigraphic ranges of Early Cretaceous representatives of the genus Dorothia are probably less restricted (see e.g., Maync, 1972). Too precise age determinations, based on their published ranges, should therefore be taken with some caution. The species of the group of Dorothia hauteriviana are a potential tool for the correlation of open-marine Early Cretaceous deposits lacking planktonic foraminifera, but their interregional stratigraphic significance needs to be tested in well-dated sections of several distant geographic areas.

The planktonic foraminifera found in Cores 64 and 67 at Site 305 are represented by very few specimens. It is therefore somewhat hazardous to use them for age determinations. Hedbergella aptica (Agalarova) (Core 64) ranges from the base of the Aptian into the Albian (Gorbatchik and Kretschmar, 1969), whereas Globigerinelloides gottisi (Chevalier) (Core 64) is known mainly from the early Aptian, but extends into the late Aptian (Sigal, 1966; Longoria, 1972). This may indicate that at least the upper part of this interval may still be of early Aptian age, although this would conflict with the published range of Dorothia zedlerae. Hedbergella sigali (Moullade) is represented by only one specimen in Core 67. This species is known mainly from the Barremian. The two specimens determined as Hedbergella globigerinelloides (Subbotina) belong to a long-ranging species which was first described from the early Albian.

The common occurrence of Spirillina sp. in the corecatcher sample of Core 20 (Site 306) is noteworthy. They were determined as Spirillina minima (Schacko), a species reported throughout the Cretaceous, and Spirillina neocomiana Moullade. The latter species is known from the Berriasian to the Barremian (Moullade, 1966). 
Interval with Dorothia hauteriviana (Moullade); Hauterivian to Barremian. (Site 303, Core 8A; Site 304, Core 14; Site 306, Cores 22 to 26)

The microfaunas from this interval are similar to those from the basal sediments cored at Sites 49 and 50 on Shatsky Rise (Leg 6 of DSDP). Douglas and Moullade (1972) dated these microfaunas as early Barremian to late Hauterivian. According to these authors, Dorothia hauteriviana (Moullade) occurs from within the Valanginian into the early Barremian. The co-occurrence of Dorothia hauteriviana and $D$. praeoxycona would indicate an early Barremian age (Douglas and Moullade, 1972, fig. 3). However, Maync (1972) extends the range of Dorothia hauteriviana to the Aptian and basal Albian.

Very rare specimens of Lenticulina ouachensis ouachensis (Sigal), a species known from the Hauterivian to the Aptian, are found in Core 22 of Site 306.

At Site 304, almost the entire interval attributed to the Early Cretaceous contains no foraminifera. The first foraminifera are found in cuttings corresponding to Core 13 which contain a few small lagenids and primitive arenaceous foraminifera. The two samples of sediments overlying the basalt (Core 14) are dominated by lagenids, but contain also Dorothia hauteriviana (Moullade), D. zedlerae (Moullade), D. praeoxycona Moullade, and D. kummi (Zedler) and are therefore attributed to the interval with Dorothia hauteriviana (for faunal lists, see Appendix A).

Core $8 \mathrm{~A}$ from Site 303, which again is the lowermost sediment core, contains only a poor and badly preserved microfauna with Dorothia hauteriviana (Moullade), Dorothia sp. cf. D. praeoxycona Moullade, and Dorothia sp. cf. D. zedlerae (Moullade), and is therefore correlated with the same interval. The overlying Core 7A contains only very few lagenids and Glomospira sp. (for faunal lists, see Appendix A).

Interval Below Lowermost Occurrence of Dorothia hauteriviana (Moullade); Early Cretaceous (undifferentiated) (Site 306, Cores 27 to 42)

Below Core 26 of Site 306, foraminifera are very rare. The microfaunas in the few cores from which residues could be obtained are generally dominated by Radiolaria. Occasionally, a few lagenids could be determined (Figure 3), but they are insufficient to date the samples and indicate merely a broad Early Cretaceous (Neocomian) age.

\section{ACKNOWLEDGMENTS}

I wish to thank the Deep Sea Drilling Project for inviting me to participate on Leg 32. The management of Esso Production Research-European granted the necessary time and assistance to take part in Leg 32 and to prepare this initial report. The scanning electron micrographs were made by R. Hockett, Exxon Production Research Company, Houston. J.F. Longoria allowed me to use the manuscript of his thesis; H.M. Bolli gave me copies of the manuscripts dealing with the Early Cretaceous foraminifera recovered during Leg 27.

\section{REFERENCES}

Bartenstein, H. et al., 1962. Leitfossilien der Mikropaläontologie: Ein Abriss herausgegeben von einem Arbeitskreis deutscher Mikropaläontologen. Berlin-Nikolassee (Gebr. Borntraeger) 432 p.

Bolli, H.M., 1959. Planktonic foraminifera from the Cretaceous of Trinidad, B.W.I.: Am. Paleontol. Bull., v. 38, p. 253-278.

Douglas, R.G. and Moullade, M., 1972. Age of the basal sediments on the Shatsky Rise, western North Pacific Ocean: Geol. Soc. Am. Bull., v. 83, p. 1163-1168.

Drushchits, V.V. and Kudryatsev, M.P. (Ed.), 1960. Atlas nizhnemelovoi fauny Severnovo Kavkaza i Kryma: Moscow (Gostoptekhizdat).

Fuchs, W., 1971. Eine alpine Foraminiferenfauna des tieferen Mittel-Barreme aus den Drusbergschichten von Ranzenberg bei Hohenems in Voralberg. Abh. Geol. Bundesanst. (Wien), no. 27.

Gorbatchik, T.N. and Kretschmar, V., 1969. Rastchlenenie apt-albskikh otlozhenii Kryma po planktonnym foraminiferam. Viestnik Moskov. Univ. Geol., 1969, no. 3, p. 4656.

Loeblich, A.R., Jr. and Tappan, H., 1961. Cretaceous planktonic foraminifera: Part I-Cenomanian: Micropaleontology, v. 7, p. 257-304.

Longoria, J.F., 1972. Stratigraphic, morphologic and taxonomic studies of Aptian planktonic foraminifera: Thesis Univ. Texas at Dallas.

Luterbacher, H. and Premoli Silva, I., 1962. Note préliminaire sur une révision du profil de Gubbio, Italie: Riv. Ital. Paleontol., v. 68, p. 253-288.

Maync, W., 1972. Lower Cretaceous foraminiferal fauna from Gorringe Bank, eastern North Atlantic. In Ryan, W.B.F., Hsü, K.J., et al., Initial Reports of the Deep Sea Drilling Project, vol. 13: Washington (U.S. Government Printing Office), p. 1075-1111.

Michael, F.Y., 1972. Planktonic foraminifera from the Comanchean Series (Cretaceous) of Texas: J. Foram. Res., v. 2 , p. 191-220.

Moullade, M., 1966. Etude stratigraphique et micropaléontologique du Crétacé inférieur de la "Fosse vocontienne.” Doc. Lab. Géol. Fac. Sci. Lyon, no. 15, 2 vols., 369 p.

1974. Zones de foraminiferes du Crétacé inférieur mésogéen. C.R. Acad. Sci. Paris, sér. D., t. 278. no. 14, p. 1813-1816.

Risch, H., 1971. Stratigraphie der höheren Unterkreide der bayerischen Kalkalpen mit Hilfe von Mikrofossilien: Palaeontographica Abt. A, no. 138, 80 p.

Scheibnerova, V., 1974. Aptian-Albian benthonic foraminifera from DSDP Leg 27 sites 259, 260 and 263 in the eastern Indian Ocean: Manuscript.

Sigal, J., 1966. Contribution à une monographie des Rosalines: 1. Le genre Ticinella Reichel, souche des Rotalipores. Eclog. Geol. Helv., v. 59, p. 185-218.

1969. Contribution à une monographie des Rosalines: 2. L'espèce Rotalipora appenninica (O. Renz, 1936), origine phylétique et taxinomie: 1st Internatl. Conf. Plankt. Microfossils, Proc., Geneva 1967, v. 2, Leiden (E.J. Brill), p. 622-639.

\section{APPENDIX A}

Early Cretaceous Foraminifera from Sites 303 and 304

Because of the scarcity of samples containing foraminifera, no distribution charts were prepared for Sites 303 and 304 . The forms determined in these two sites are therefore given in the following lists. 
Site 303:

Sample 7A, CC: very poor and poorly preserved faunule. Glomospira sp. sp. (a.o. G. irregularis [Grzybowski], G. charoides [Parker and Jones])

Astacolus sp. sp. (a.o. A. planiusculus [Reuss], Astacolus sp. aff. A. major [Bornemann])

Pseudonodosaria humilis (Roemer)

Ramulina sp.

Sample 8A, CC: very poor and poorly preserved microfauna.

Hyperammina? sp.

Haplophragmoides concavus (Chapman)

Dorothia hauteriviana (Moullade)

Dorothia sp. cf. D. praeoxycona Moullade

Dorothia sp. cf. D. zedlerae (Moullade)

Lenticulina sp. sp. ex gr. L. muensteri (Roemer)

Astacolus vetustus (d'Orbigny)

Marginulinopsis sp. cf. M. parkeri (Reuss)

Vaginulina biochei Berthelin

Dentalina sp. sp. (a.o. D. communis d'Orbigny, D. linearis Reuss, D. legumen Reuss)

Nodosaria sp. aff. N. sceptrum Reuss

Pseudonodosaria humilis (Roemer)

Ramulina sp.

\section{Site 304}

Core 13, "cuttings" from core catcher: very poor microfauna, composed mainly by small lagenids, relatively well preserved.

Hyperammina? sp.

Tolypammina? sp.

Haplophragmoides? sp.

Lenticulina sp. sp. ex gr. L. muensteri (Roemer)

Lenticulina sp. aff. L. crassata Kaptarenko-Chernoussova

Lenticulina nodosa (Reuss)

Astacolus calliopsis (Reuss)

Astacolus planiusculus (Reuss)

Marginulinopsis parkeri (Reuss)

Dentalina sp. sp. (a. o. D. communis d'Orbigny, D. serrata

Eichenberg, D. cylindroides Reuss, D.? debilis Berthelin)

Nodosaria sp. sp.

Pseudonodosaria humilis (Roemer)

Globulina sp.

Core 14, Section I (strongly disturbed core): relatively rich but poorly

preserved microfauna dominated by lagenids and Dorothia sp. sp.

Hyperammina? sp.

Tolypammina? sp.

Ammodiscus tenuissimus (Guembel)

Glomospira sp. sp. (a. o. G. charoides [Parker and Jones])

Haplophragmoides? sp.

Textularia sp. aff. T. inversa (Terquem)

Eggerella? sp.

Arenobulimina sp.

Dorothia hauteriviana (Moullade)

Dorothia praeoxycona Moullade

Dorothia kummi (Zedler)

Dorothia sp.

Lenticulina sp. sp. ex gr. L. muensteri (Roemer)

Lenticulina crassata Kaptarenko-Chernoussova

Lenticulina sp. ex gr. L. quenstedti (Guembel)

Lenticulina subalata (Reuss)

Darbyella sp. aff. D. calva (Wisniowski)

Astacolus calliopsis (Reuss)

Astacolus dilectus (Reuss)

Astacolus planiusculus (Reuss)

Astacolus vetustus (d'Orbigny)
Frondicularia $\mathrm{sp.}$

Vaginulina biochei Berthelin

Dentalina sp. sp. (a. o. D. cylindroides Reuss, D. terquemi d'Orbigny, $D$. ? debilis Berthelin)

Pseudonodosaria humilis (Roemer)

Lingulina pupa (Terquem)

Globulina sp.

Ramulina $\mathrm{sp}$

Sample 14, CC: relatively rich, but poorly preserved assemblage dominated by lagenids and Dorothia sp. sp.

Hyperammina? sp.

Tolypammina? sp.

Glomospira sp.

Ammodiscus sp. sp.

Haplophragmoides concavus (Chapman)

Dorothia hauteriviana (Moullade)

Dorothia kummi (Zedler)

Dorothia praeoxycona Moullade

Dorothia sp.

Lenticulina sp. sp. ex gr. L. muensteri (Roemer)

Lenticulina crassata Kaptarenko-Chernoussova

Lenticulina sp. aff. L. nodosa (Reuss)

Lenticulina subalata (Reuss)

Darbyella sp. aff. D. calva (Wisniowski)

Astacolus calliopsis (Reuss)

Astacolus sp. aff. A. insectus (Schwager)

Astacolus planiusculus (Reuss)

Astacolus vetustus (d'Orbigny)

Marginulinopsis parkeri (Reuss)

Frondicularia $\mathrm{sp}$

Vaginulina biochei Berthelin

Dentalina communis d'Orbigny

Dentalina linearis (Roemer)

Dentalina serrata Eichenberg

Nodosaria sp. sp.

Pseudonodosaria humilis (Roemer)

Lingulina sp. aff. L. biformis Bartenstein and Brand

Globulina sp.

Pyrulina sp. aff. P. gutta d'Orbigny

Ramulina sp. sp.

\section{APPENDIX B}

\section{Early Cretaceous Ostracodes}

The washed residues from the Early Cretaceous sections cored during Leg 32 contain only very few ostracodes. They were submitted to H.J. Oertli (SNPA, Pau) for examination. He determined the following forms:

Site 305:

Sample 41, CC-Cytherella sp.

Sample 46, CC-Cytherella sp.

Sample 64, CC-Bythocypris sp. Site 306:

Sample 3, CC-Cytherella sp., Brachycythere sp.

Sample 24, CC-Bairdia sp. sp.

Sample 37, CC-Bairdia sp.

Sample 38, CC-Bairdia sp.

Sample 4I-I, 126-128 cm-Bairdia sp., Robsoniella? sp.

Sample 42-1, 116-118 cm-Bairdia sp., Bythocypris sp.

In addition, he states: "Ostracodes are very scarce throughout, poorly preserved and monotonous in their generic and specific configuration. Of none of the above mentioned species, identity with known species could be found. The generic composition seems to be that of an oceanic (deeper than shelf) environment." 


\section{PLATE 1}

All figures $\times 75$. (a) spiral view; (b) umbilical view; (c) lateral view.

Figure $1 \quad$ Rotalipora brotzeni (Sigal), 305-39, CC.

Figure 2 Rotalipora apenninica (Renz), 305-41, CC.

Figure 3 Rotalipora gandolfii Luterbacher and Premoli Silva, 305-39, CC.

Figures 4, 5 Globigerinelloides eaglefordensis (Moreman), 306$3, \mathrm{CC}$.

Figures 6,7 ISchackoina cenomana (Schacko), 306-3, "cuttings."

Figure 8 Hedbergella delrioensis (Carsey), 305-46, CC.

Figures 9, 10 Hedbergella amabilis Loeblich and Tappan.

9. 306-3, CC.

10. $306-4-1,120-122 \mathrm{~cm}$. 


\section{PLATE 1}
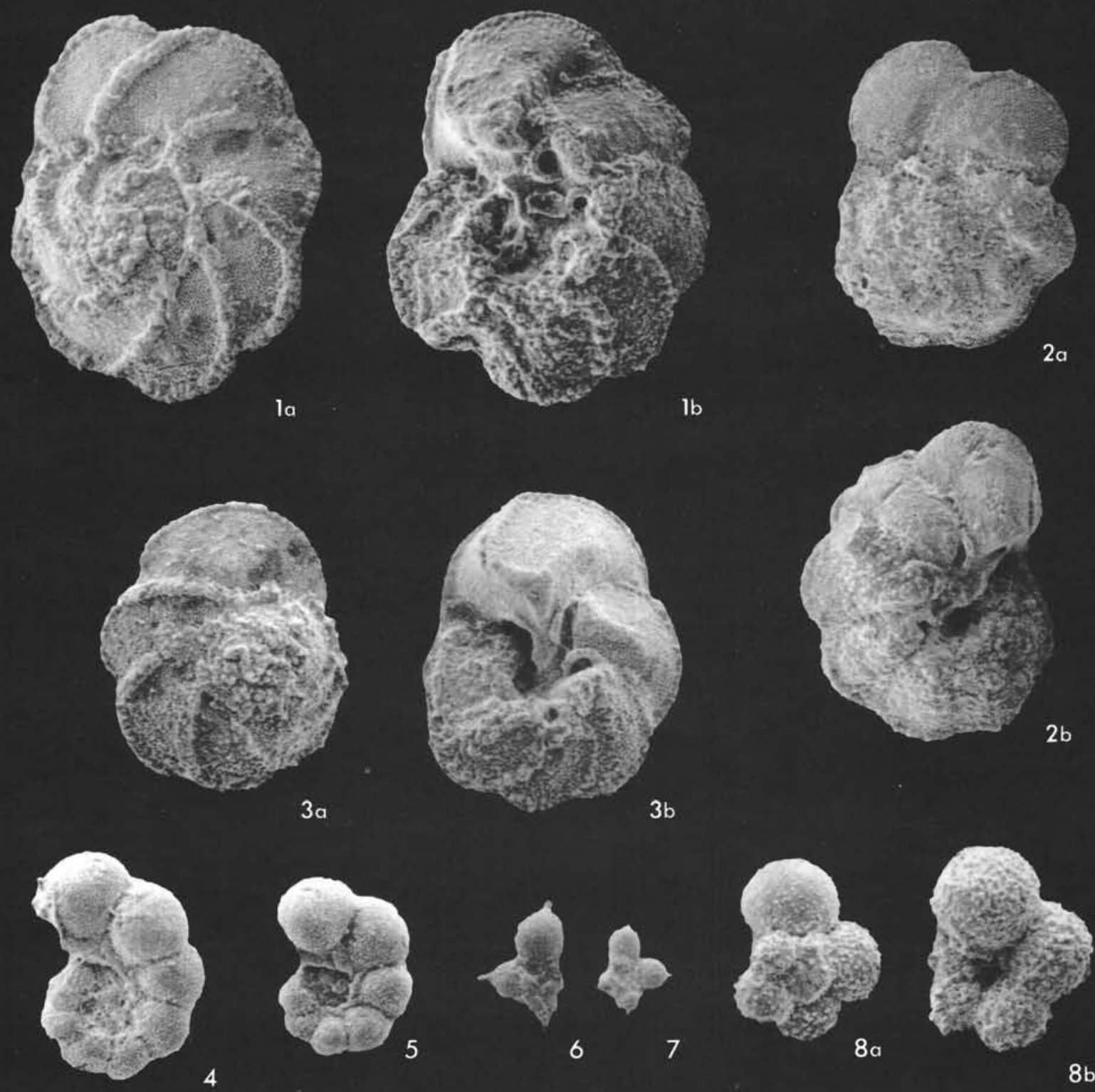

4

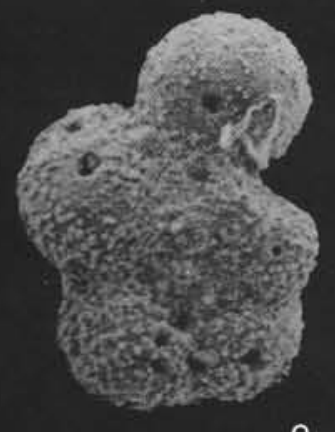

$9 a$

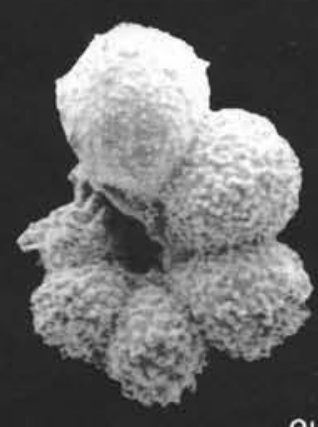

$9 b$

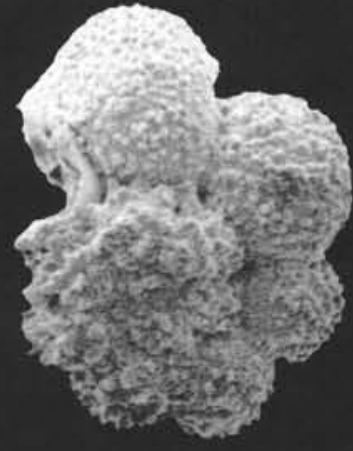

$10 a$

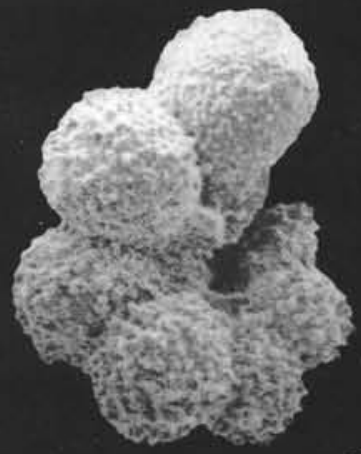

$10 \mathrm{~b}$ 


\section{PLATE 2}

All figures $\times 75$. (a) spiral view; (b) umbilical view; (c) lateral view.

Figure 1 Hedbergella brittonensis Loeblich and Tappan, $305-44$, CC.

Figure $2 \quad$ Globigerinelloides sp., 305-57, CC.

Figure 3 Ticinella sp. aff. T. madecassiana Sigal, 305-57, CC.

Figures 4-8 Gubkinella(?) graysonensis (Tappan).

4. $305-60-1,100-102 \mathrm{~cm}$.

5. $305-42$, CC.

6. $306-44, \mathrm{CC}$

7, 8. 305-46, CC.

Figure 9 Conorotalites sp. aff. C. aptiensis (Bettenstaedt), 305-40, "cuttings."

Figures 10, 11 Osangularia californica Dailey, 305-46, CC.

Figure 12 Vaginulina biochei Berthelin, 306-20, CC. 
PLATE 2
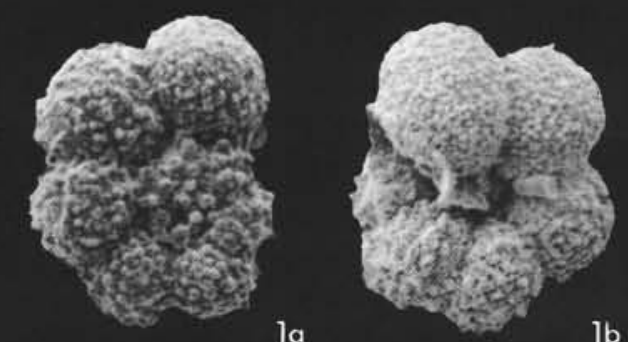

Ib

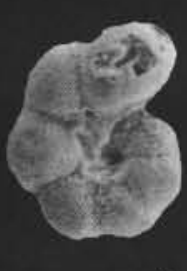

2

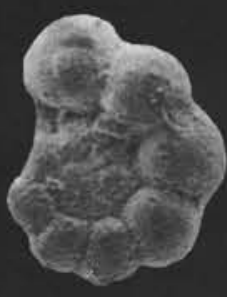

$3 a$

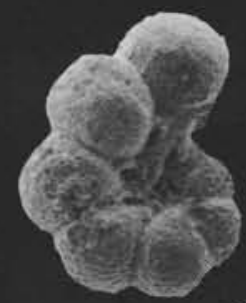

$3 b$
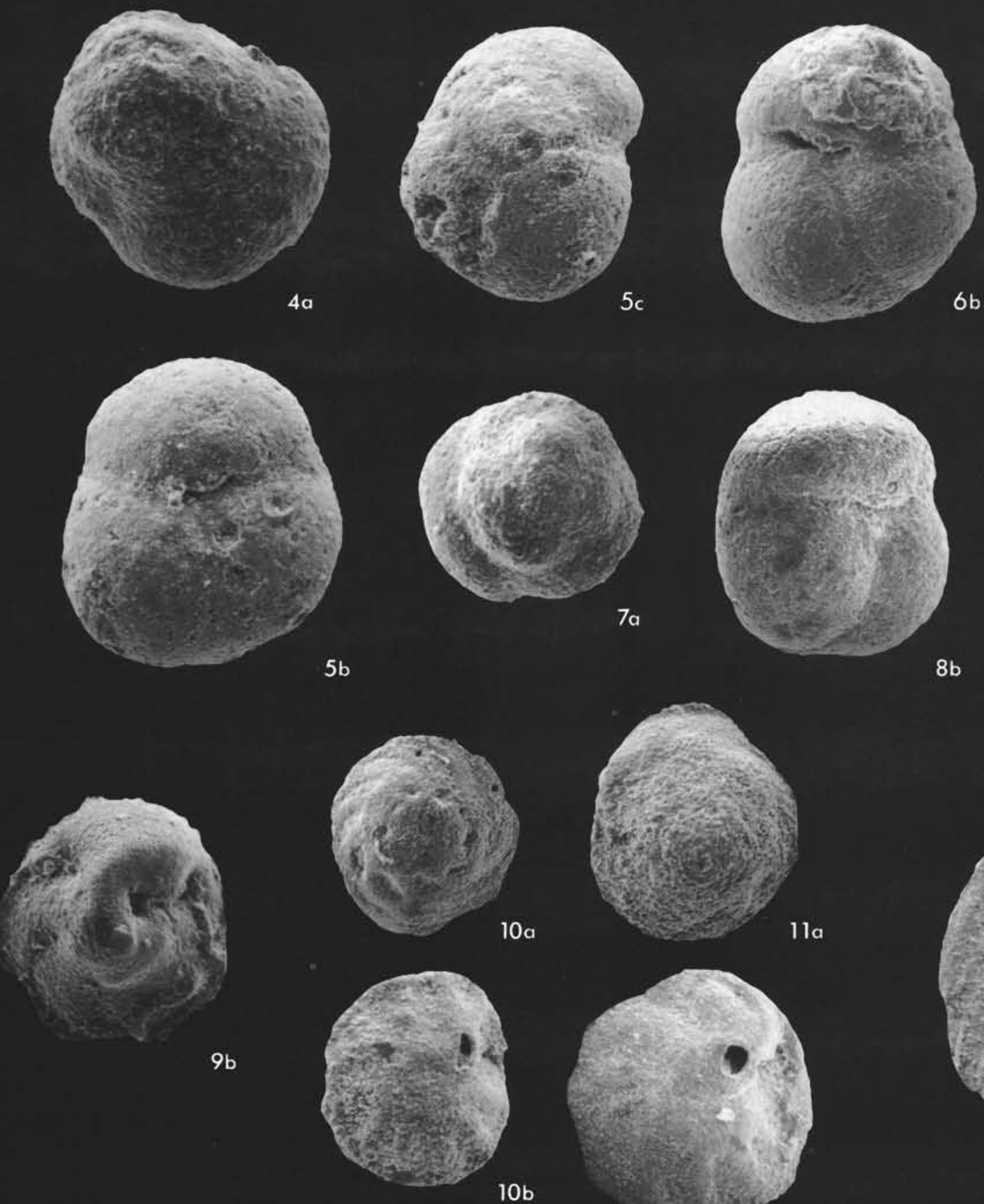

$8 b$

$9 b$

$10 \mathrm{~b}$ 


\section{PLATE 3}

(a) spiral view; (b) umbilical view.

Figures 1,2 Darbyella sp. aff. D. calva (Wisniowski), $\times 75$.

1. 304-14, 1 .

2. $304-14, \mathrm{CC}$.

Figures 3,4 Pleurostomella reussi Berthelin, 305-60-1, 100-102 $\mathrm{cm} . \times 75$.

Figure 5 Dentalina $\mathrm{sp} ., 306-38$, CC. $\times 75$.

Figures 6-8 Ramulina sp. $\times 75$.

6. $305-57$, CC.

7. $305-46, \mathrm{CC}$.

8. $306-38, \mathrm{CC}$.

Figure 9 Marginulina inaequalis Reuss, 306-22, CC. $\times 75$.

Figures 10,11 Spirillina neocomiana Moullade, 306-20, CC. $\times 75$.

Figure 12 Spirillina minima Schacko, 306-20, CC. $\times 75$.

Figures 13, 14 Spirillina minima Schacko, 306-20, CC. $\times 150$.

Figure 15 Pseudoclavulina gaultina (Morozova), 306-3, “cuttings." $\times 50$.

Figure $16 \quad$ Pseudoclavulina $\mathrm{sp} ., 306-4-1,100-122 \mathrm{~cm} . \times 75$. 
PLATE 3

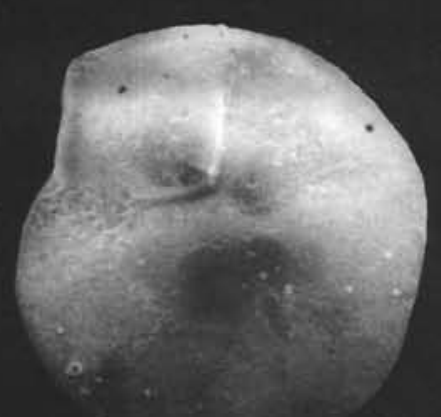

lb
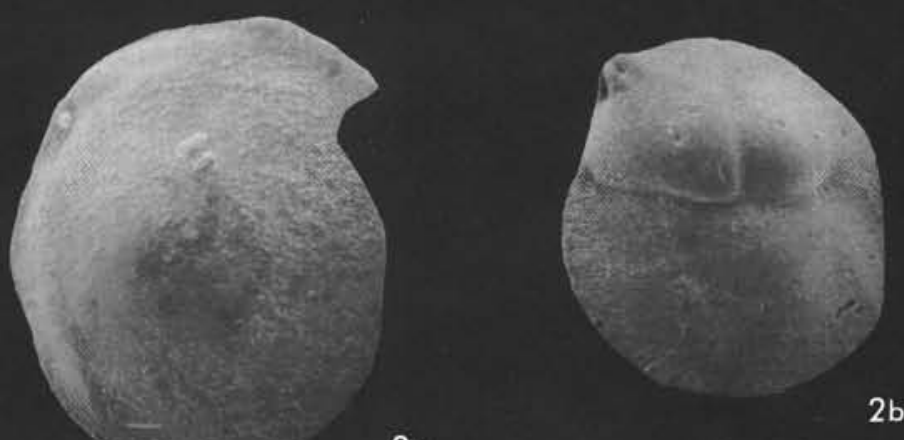

$2 a$
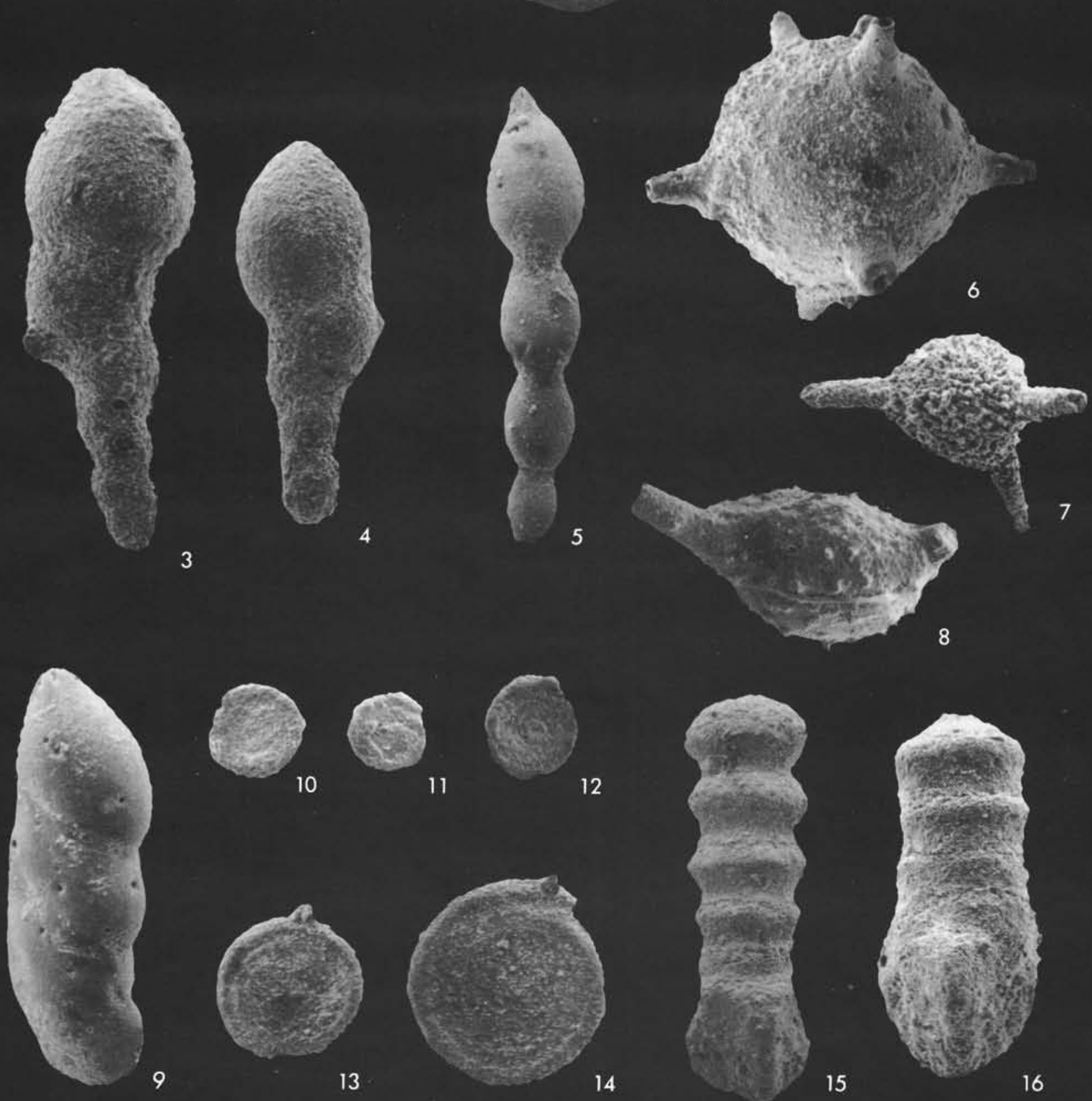


\section{PLATE 4}

All figures $\times 75$.

Figure 1 Tritaxia pyramidata Reuss, 305-60-1, 100-122 cm.

Figure 2 Spiroplectammina sp., 306-4, CC.

Figures 3,4 Eggerella(?) sp., 304-14-1.

Figure 5 Dorothia sp. aff. D. zedlerae Moullade, 304-14, CC.

Figures 6, 7 Dorothia sp. aff. D. oxycona (Reuss), 304-14, CC.

Figure $8 \quad$ Gaudryina sp., 305-59, CC.

Figure 9 Dorothia hauteriviana (Moullade), 304-14, CC.

Figures 10-14 Dorothia praeoxycona Moullade.

$10,12,14.306-24, \mathrm{CC}$.

11, 13. 306-26, CC.

Figures 15, 16 Dorothia zedlerae Moullade, 306-19, CC.

Figures 17-20 Dorothia ouachensis (Sigal).

17, 19, 20. 306-24, CC.

18. 306-26, CC. 


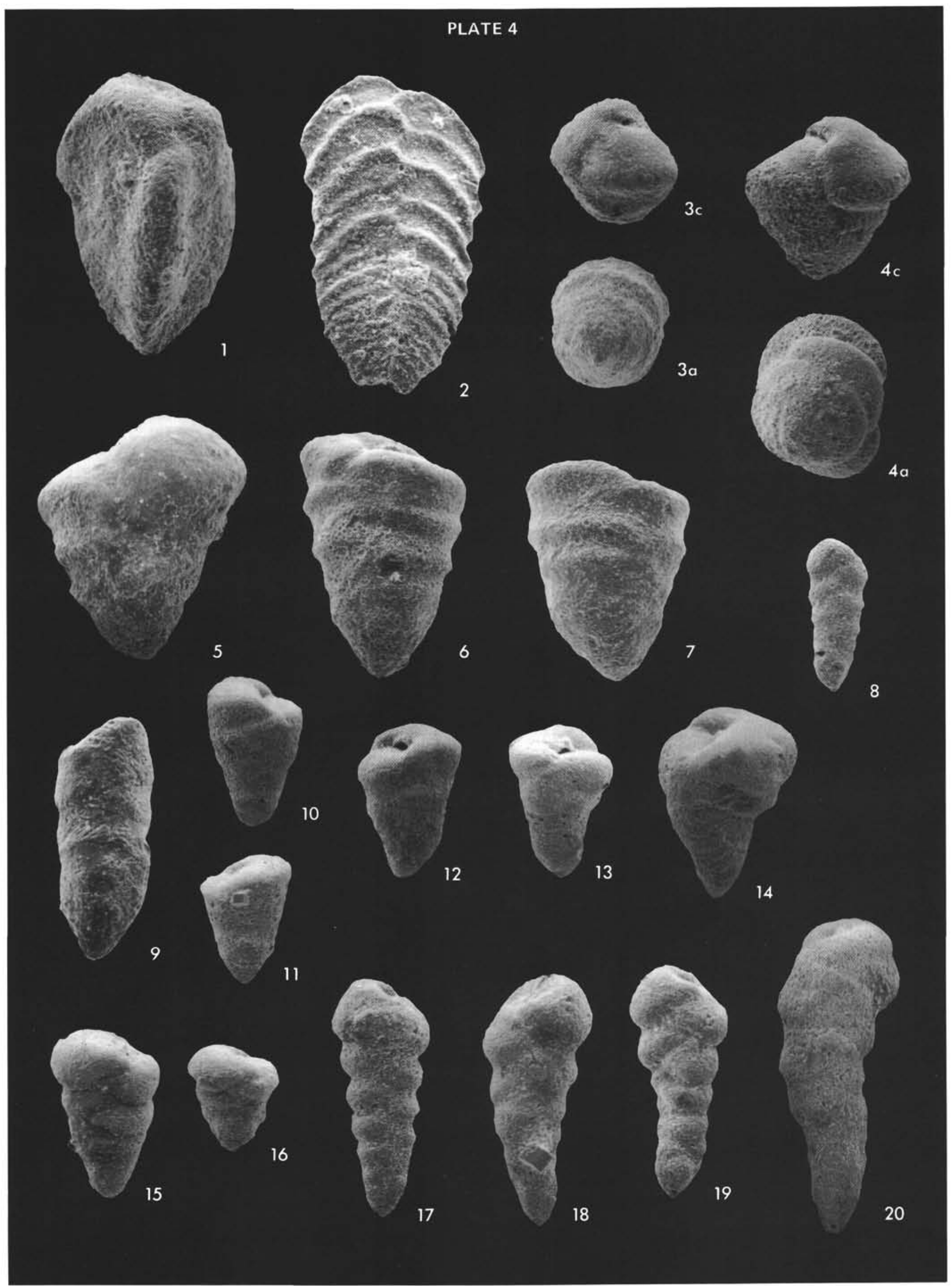


PLATE 5
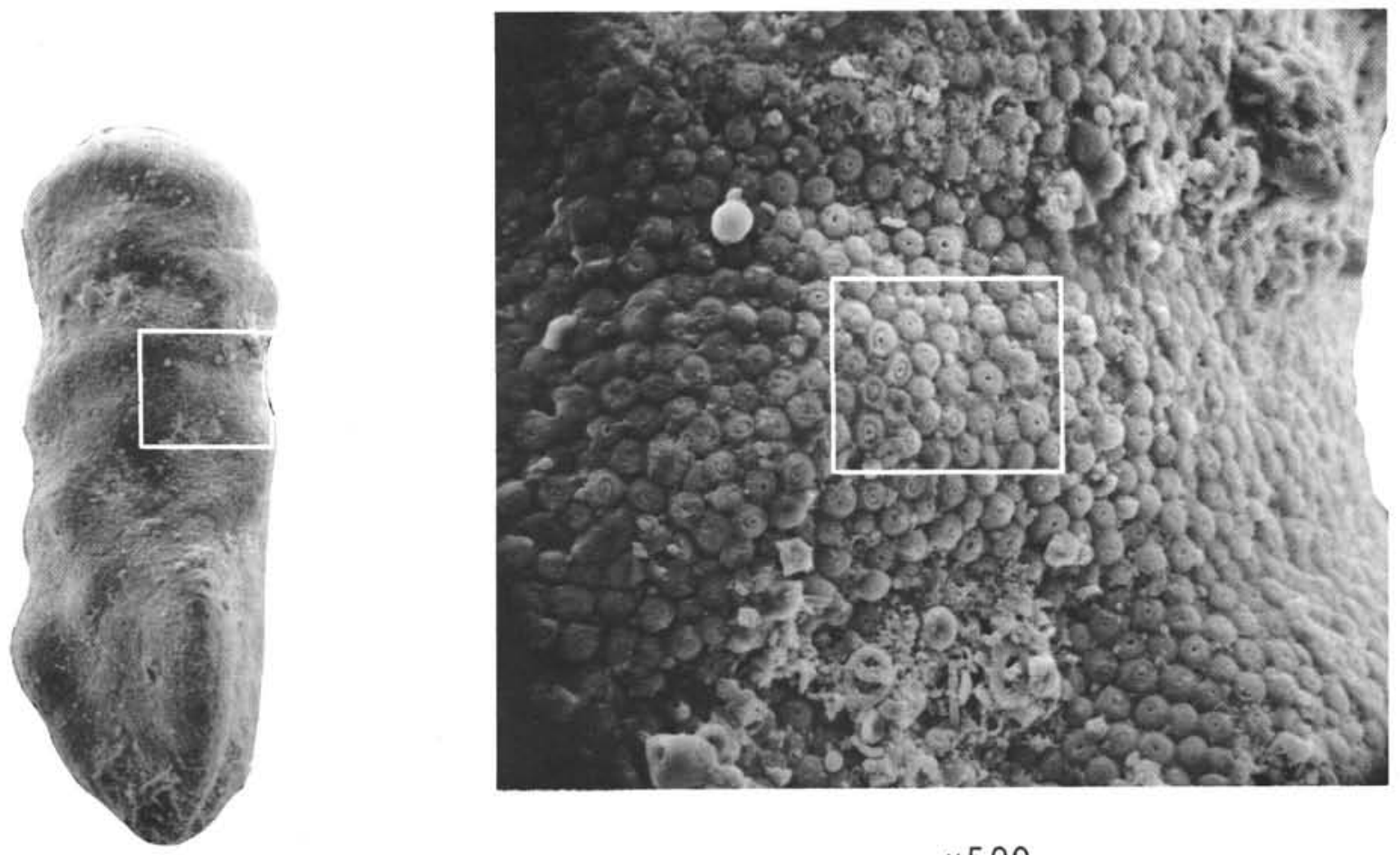

$\times 500$

$\times 75$

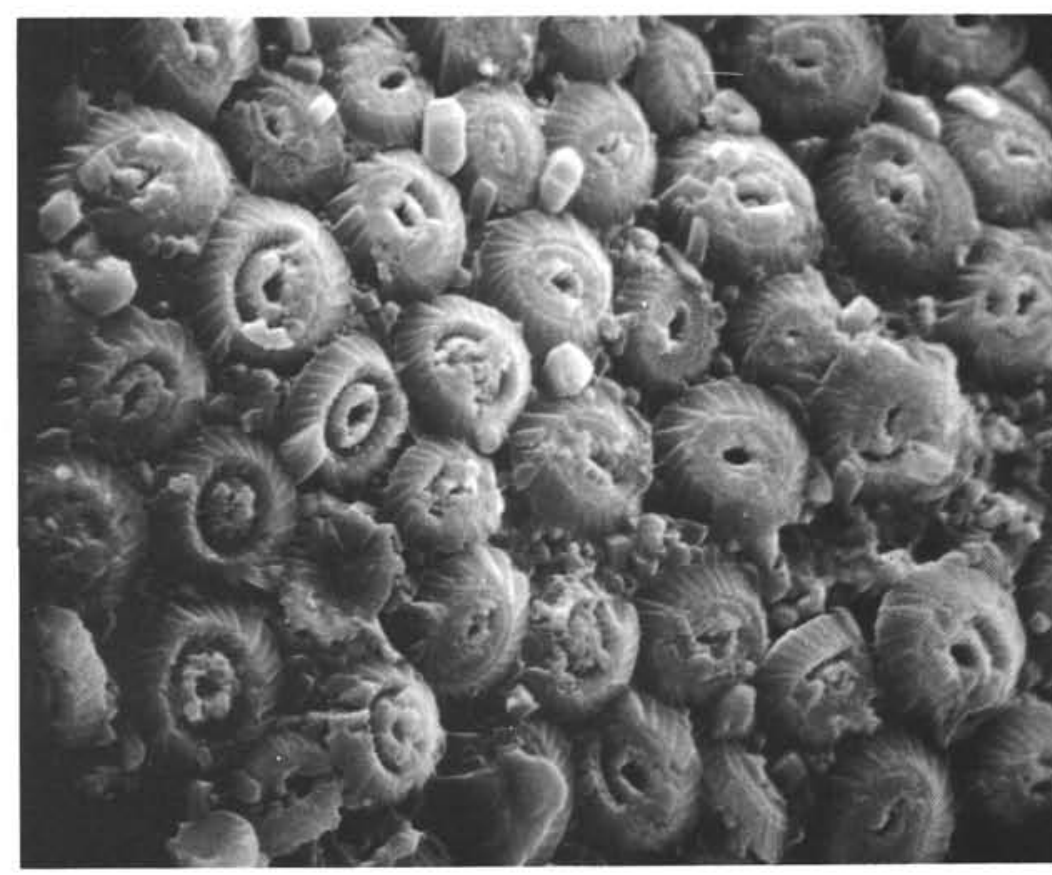

$\times 2000$

Gaudryina compacta Grabert, 305-58, CC. The wall consists almost exclusively of neatly arranged Watznaueria sp. 